28. Shkuratov, Y. G. (Ed.) (2008). 200 let astronomii v Har'kovskom universitete [200 years of astronomy at Kharkiv University]. Kharkiv: Kharkiv National University, 632 p. (in Russian).

29. Slastenov, A. I. (1955). Astronomija v Har'kovskom universitete za 150 let (1805-1955) [Astronomy at Kharkov University for 150 years (1805-1955)]. Kharkov: Kharkov A. M. Gorky State University, 184 p. (in Russian).

30. Struve, L. (1911). Beobachtung der totalen Mondfinsternis vom 16, November 1910 auf Sternwarte in Charkow. Astronomische Nachrichten, 186, issue 4460, p. 329-331.

31. Struve, L. (1901). Ueber die Constante der Pracession und die eigene Bewegung der Sonne. Astronomische Nachrichten, 156, issue 3729-3730, p. 129-148. doi:10.1002/asna.19011560902

32. Struve, L. (1902). Zur Bestimmung der Pracessionsconstante und der eigenen Bewegung des Sonnensystems. Astronomische Nachrichten, 159, issue 3816, p. 377-384.

33. Struve, L. O., Jewdokimow, M. M. (1904). Annales de l'Observatoire astronomique de l'Université imperiale de Kharkow, vol.1, Kharkow : M. Silberberg, 74 p.

34. Struve, L. O., Jewdokimow, M. M. (1915). Kratkij otchet ob jekspedicii dlja nabljudenija polnogo solnechnogo zatmenija 8/21 avgusta 1914 goda [Brief report of the expedition to observe the total Solar eclipse on August 8/21, 1914]. Zapiski Imperatorskogo Har'kovskogo universiteta za 1914 god. Kharkov: M. Silberberg, p. 1-4 (in Russian).

35. Zakhozhaj, V.A. (2002). Razvitie galakticheskoj i vnegalakticheskoj astronomii v Har'kovskom universitete [Development of galactic and extragalactic astronomy in Kharkov University]. Visny 'k astronomichnoyi shkoly', vol. 3, issue 2, p. 26-41 (in Russian). doi: 10.18372/24116602.03 .2026

Received 15.02.21

Accetpted 05.03.21

DOI: $10.15421 / 272106$

УДК 94(477)»18»(092):930.1(1-15)

Т. Ф. Литвинова, А. І. Шелест

Дніпровський національний університет імені Олеся Гончара, Дніпро, Украӥна

\title{
ОБРАЗ ЗАХОДУ В УЯВЛЕННЯХ Г. П. ГАЛАГАНА
}

\author{
E-mail: litvinova.tf@i.ua \\ ORCID: https://orcid.org/0000-0002-8682-2819 \\ ResearcherID: G-1951-2019 \\ E-mail: bastyadelimon@gmail.com
}

Анотація. Мета статті полягає у реконструкції уявлень Г. П. Галагана про Захід. Актуальність теми обумовлена ії дисциплінарним виміром - «нова просторова історія», «нова історична біографістика», імагологія, соціальна історія, та вибором персоналії, яка виступає метою і засобом вивчення уявлень, оскільки Григорій Павлович Галаган, відомий меценат, громадський діяч, представник інтересів спільноти Лівобережної України перед місцевим та центральним урядом, був водночас репрезентантом дворянської культури свого часу. Вивчення просторових уявлень окремих індивідів або соціальних груп дає можливість поглянути на процес міжкультурної взаємодії з точки зору його учасників та співставлення «свого», «чужого», «іншого», що тісно пов'язано з проблемою самопізнання, пошуку самоідентифікації, вироблення колективної ідентичності, у тому числі й національної. Методологічною основою стали принципи науковості та історизму, які орієнтують досліджувати епоху та людину певної доби з урахуванням особливостей тогочасної культури, загальнонаукові методи (аналіз та синтез) та методи історичної науки (хронологічний, історико-генетичний, історико-порівняльний, історіографічний, джерелознавчий), а також підходи «нової просторової історії» з орієнтацією на вивчення соціального простору та «нової історичної біографістики» з їі орієнтацією на вивчення «людини другого плану». 
Основні результати полягають у з'ясуванні місця подорожей у формуванні просторових уявлень соціальної еліти. Першочергову увагу звернуту на закордонні мандрівки, які стали важливою складовою дворянської культури першої половини XIX ст. На основі аналізу джерельного комплексу, що представлений щоденником-журналом молодого Г. П. Галагана та приватним листуванням, які містять розлогі рефлексії щодо вражень від закордонних мандрівок 1841-843рp., 1850-1851рр., 1861 р., 1866 р., виявлено зміни у сприйнятті країн та народів Західної Свропи, ставлення до західної цивілізації та до малої Батьківщини, а також особливості його самоідентифікації.

Ключові слова: Г. П. Галаган, дворянство, Гранд-тур, травелоги, Західна Європа, Росія, Лівобережна Україна.

\section{T. F. Lytvynova, A. I. Shelest}

\section{Oles' Honchar Dnipro National University, Dnipro, Ukraine}

\section{IMAGE OF THE WEST IN THE VIEWS OF G. P. GALAGAN}

Abstract. The purpose of the article is to reconstruct Galan's ideas about the West. The urgency of the topic is due to its disciplinary dimension - «new spatial history», «new historical biography», imagology, social history and the choice of personality, which serves as the purpose and means of studying ideas, as Grigory Pavlovich Galagan, famous philanthropist, public figure, representative of the Left Bank community Ukraine before the local and central government, was at the same time a representative of the aristocratic culture of his time. The study of spatial representations of individuals or social groups provides an opportunity to look at the process of intercultural interaction in terms of its participants and the comparison of «own», «foreign», «other», which is closely related to the problem of self-knowledge, self-identification, collective identity, including national. The methodological basis was the principles of science and historicism, which orient to study the era and man of a certain era, taking into account the peculiarities of contemporary culture, general scientific methods (analysis and synthesis) and methods of historical science (chro Balyshev, M. A. Development of astronomy in Kharkiv at the beginning of the XX century (1900 - 1917)nological, historical-genetic, historical-comparative, historiographical, source), and also the approaches of the «new spatial history» with the focus on the study of social space and the «new historical biography» with its focus on the study of the «second person». The main results are to find out the place of travel in the formation of spatial representations of the social elite. The primary attention is paid to foreign travels, which became an important component of the aristocratic culture of the first half of the nineteenth century. Based on the analysis of the source complex, presented by the diary-magazine of the young G. P. Galagan and private correspondence, which contain extensive reflections on the impressions of foreign travels of 1841-843, 1850-1851,1861, 1866, revealed changes in the perception of countries and peoples of Western Europe, attitudes to Western civilization and the small country, as well as features of its self-identification.

Keywords: G. P. Galagan, nobility, Grand Tour, travelogues, Western Europe, Russia, Left Bank Ukraine.

Вступ. Захід, Західна Європа - умовні географічні області зі своїми культурними особливостями та історією. Безперечно, можна говорити про вплив Заходу на освічену публіку Російської імперії, частину якої протягом тривалого часу становив значний масив земель сучасної України. Водночас слід зауважити, що певні її території безпосередньо знаходились у складі тих держав, які й відносять до умовної просторової площини, що визначається поняттями «Захід» або «Західна Європа». Можна сказати, що Захід не перестає впливати на певні сторони нашого життя й по сьогодні. Для сучасної України вже не перший рік постає питання про євроінтеграцію, що є прямим свідченням необхідності вивчення такої сторони взаємовідносин, як уявлення людей або певного прошарку суспільства про країни Західної Європи, їх вплив на свідомість або сприйняття цієї частини континенту.

Питання про те, як сприймалась європейська культура на рівні окремої людини або соціальної групи, залученої до процесу взаємодії культур, ставлення до цінностей $\mathrm{i}$ культурних традицій західної цивілізації, механізми набуття досвіду західної модернізації тощо вивчено недостатньо. Ці міркування й вплинули на вибір теми даної статті, 
актуальність якої обумовлена також їі дисциплінарним виміром, - «нова просторова історія», «нова історична біографістика», імагологія, соціальна історія. У світлі інтересу сучасної гуманітаристики до теми «людина в історії», до особистого досвіду осмислення й переживання історичних подій, вивчення просторових уявлень окремих індивідів або соціальних груп дає можливість поглянути на процес міжкультурної взаємодії зсередини, 3 точки зору його учасників, виділити актуальні для них проблеми. Спостереження за певними культурними ареалами та, відповідно, іншими народами неминуче пов'язано зі співставленням «свого» та «чужого», «іншого», з їх оцінкою на основі власної системи цінностей [9], що, своєю чергою, веде до самопізнання, сприяє виробленню самоідентифікації, колективної ідентичності, у тому числі й національної. Це також важливо з огляду на вирішення проблеми формування уявлень про власну національну територію, яка у вітчизняній історіографії тільки починає розроблятись [5; 15].

Попри те, що соціальна еліта XIX ст., зокрема дворянство різних українських регіонів, так чи інакше вивчалися, історики практично не звернули увагу на його просторові уявлення, що засвідчують й історіографічні огляди $[3 ; 16 ; 22]$. Однак без цього навряд чи можна говорити про грунтовність вивчення цієї соціальної групи та вагомість її внеску у формування національної ідентичності, у тому числі й уявлень про національну територію. Тому на початковому етапі розробки проблеми вважаємо за доцільне звернутися до поглядів, уявлень окремих персоналій. Вибір особи Г. П. Галагана (1819-1888рр.) пояснюється тим, що цей великий поміщик, доволі відомий меценат, громадський та державний діяч був представником інтересів спільноти Лівобережної України перед місцевим та центральним урядом і водночас репрезентантом дворянської культури свого часу.

Значення цієї персоналії для української культури усвідомлювали ще сучасники. Невипадково відразу після смерті Г. П. Галагана були написані короткі біографії. У недавній історіографії різним напрямам його діяльності присвячено значну кількість різножанрових праць, які загалом проаналізовані в історіографічних частинах дисертацій Т. В. Ткаченко, А. Г. Тимошенка [19]. Кількість публікацій збільшилася останнім часом у зв'язку з 200-річним ювілеєм 3 дня народження. Особливо слід зазначити численні роботи М. М. Будзар та С. А. Ковальова, які розробляють різні аспекти життя та світосприйняття Галагана, намагаючись зняти глянець з особи мецената, показуючи іiі у всій складності людської долі $[6 ; 7 ; 13 ; 14]$. Таку ж мету мали й фахівці, які підготували спеціальний ювілейний випуск регіонального культурологічного часопису «Прилуки. Фортеця» [17]. Однак, навіть представляючи інформаційні можливості текстів Галагана, історики не зупинились на його уявленнях про Захід, що важливо в контексті проблеми самоідентифікацї, яку в даному разі тримаємо у фокусі своєї уваги.

Джерельну основу статті складають так звані еgо-документи - епістолярний комплекс та автобіографічні тексти (щоденник-журнал) Галагана, які умовно об'єднано у групу тревелогів, адже значне місце тут відведено саме опису вражень від закордонних мандрівок. Публікацію цих джерел було здійснено у 2019 та 2020 рр. київськими істориками М. М. Будзар та С. А. Ковальовим, ентузіазм яких зробив можливим ознайомлення широкої публіки зі значною частиною великого масиву паперів зі збереженого архіву родини Галаганів [1;11].

Виклад основного матеріалу. 3 XIX ст. Російська імперія стала частиною не тільки військово-політичного, а й культурного простору Свропи. Інформацію про європейські країни публіка нерідко отримувала саме з описів мандрівників, які активно публікували результати своїх спостережень у різних журналах [12]. Перша половина XIX ст. була насичена історично важливими подіями, що також залишили глибокий слід у російському суспільстві й змінили його ставлення до Заходу [10, с. 98]. Причини, мотивації та обставини поїздок дворянства за кордон могли бути різними. Одним із ключових феноменів, що характеризував європейську елітарну культуру, модель виховання, був Гранд-тур (Grand Tour). Цей термін з'явився в англійській літературі на початку XVIII ст. [20, с. 51] і у його класичному вузькому розумінні означав тривалу закордонну подорож з освітньою метою, яку в супроводі наставника здійснювали сини 
аристократичних родин [8, с. 1042-1043]. Наприкінці XVIII - в першій половині XIX ст. поїздки дворянства Російської імперії стають поширеною культурною практикою. Типове розмаїття подорожей простягається від дослідницьких до службових та гостьових, від паломництва по монастирях до поїздок на навчання за кордон, від відвідувань цілющих вод у Спа до мандрівок на перші російські курорти [21, с. 598].

Засоби пересування та самі прогулянки демонстрували відповідність дворянському способу життя. Починаючи з останньої третини XVIII ст. карета перетворилася на статусний символ. Нові назви, що давалися поїздкам, наприклад, запозичене 3 французької «вояж», відвідини гостей - «візит» - маркували поширення нових практик і вплив західноєвропейської літератури про подорожі. Зміна місць, поїздки на навчання, можливість розширити свої горизонти стали складовою виховання. Трансфер подорожей включав у себе знання, досвід, практики та матеріальну культуру. 3 сатиричних творів, які набули поширення у другій половині XVIII ст., можна чітко простежити орієнтацію дворянства на західноєвропейські, передусім французькі, моделі, їх запозичення [21, c. 599].

Практика освітнього Гранд-туру серед російського дворянства набирала обертів через зміну уявлень про те, що необхідно знати вихованій людині. Важливу роль відігравала мода на навчання у престижному університеті або школі, практично обов'язкове вивчення щонайменше двох живих іноземних мов, зазвичай французької і німецької, переконання, що поїздка за кордон дозволяє довести до високого рівня розпочату раніше освіту, широке засвоєння вищим суспільством європейської культури та навичок соціальної поведінки [4, с. 420-421]. Виїзд до закордонних шкіл набув поширення й в української шляхти/дворянства впродовж другої половини XVIII ст., яка прагнула давати своїм синам закордонну освіту.

Головними країнами, які слідувало відвідувати, були Італія, Франція і Англія. До цих трьох основних додавались Швейцарія, Голландія, Південні Нідерланди. Більш скромно у цьому відношенні виглядали німецькі держави та Австрія (включаючи Угорщину, Чехію і т. д.). Прихована філософія освітньої подорожі полягала у тому, що, будучи націленою на придбання різнобічних знань, вона водночас стала засобом утвердження та самореалізації дворянства в якості соціальної еліти [4, с. 429-437].

Окрім освіти, важливим мотивом від'їзду за кордон стало лікування на європейських курортах. Зрештою, на підгрунті освітніх і лікувальних практик мандрування постав туризм - соціокультурне явище, в якому сполучилися мотиви фізичного і духовного оздоровлення, урізноманітнення світовідчуття та розширення меж власного комунікаційного поля. Цьому сприяв романтизм з його орієнтацією на природність та історизм. Важливим стимулом було очікування естетичної насолоди від природних феноменів і старожитностей [1, с. 9-10].

Можна припустити, що знайомство Григорія Павловича Галагана із Заходом розпочалося через сімейні перекази. Його предки, вихідці з козацько-старшинського розу [6, с. 131] - дворяни, землевласники Полтавщини та Чернігівщини, здобували різнобічну освіту в Кенігсберзі та Лейпцигу, займали різні досить поважні державні посади, жили у Києві та Петербурзі, часто подорожували за кордон - до Німеччини, Франції, Італії [18, с. 170]. Вихователем Г. П. Галагана був слов’янофіл, ад’юнктпрофесор математики Санкт-Петербурзького університету Ф. В. Чижов, який до того стажувався за кордоном. Йому Галаган вважав себе зобов'язаним усім - своїми розумовими й моральними інтересами, переконаннями, дорогим для нього зближенням 3 кращими зі слов'янофілів - І. С. Аксаковим, Ю. Ф. Самаріним. Ф. В. Чижову також вдалося розвинути у свого вихованця прагнення до самовдосконалення. Загальні принципи виховання дворянства у дусі західноєвропейського стилю, новий статус i нова культура дворянського стану, який багато в чому наслідував або зазнав впливу Західної Європи, слов'янофільський гурток, вплив епохи у цілому, зовнішньополітичних подій, розвиток та поширення ліберально-демократичних тенденцій, безумовно, позначалися на уявленнях про Західну Європу та стали джерелами просторових переконань Г. П. Галагана. 
Упродовж свого життя Григорій Павлович здійснив чотири подорожі Західною Європою. Перша охоплювала 1841-1843 рр., друга - 1850-1851, третя - 1861 р. і остання була у 1866 р. Під час різних закордонних поїздок його супроводжував або він перетинався зі своїм наставником Ф. В. Чижовим чи матір'ю К. В. Галаган, подорожував разом з дружиною та сином. У 1841-1843 pр. він відвідав Австрійську державу (Моравію, Сілезію, Богемію), Німеччину (Баварію), Бельгію та Італію, у 1850-1851 pp. - Німеччину, Бельгію, Англію, Францію, у 1861 р. - Німеччину, Бельгію, Італію, у 1866 р. - Австрію, Баварію, Швейцарію, Францію.

Враження Г. П. Галагана від побаченого під час його першої закордонної мандрівки 1841-1843 pр. він виклав на сторінках свого юнацького журналу, в листах до матері, потім дружини й сина, у дорожніх нотатках. Він писав про свої думки, фіксував спостереження про людей, народи, їх зовнішність, одяг, поведінку, релігію, звичаї, самосприйняття, про місцевість, яку бачив навколо себе (природно-географічні умови), культуру (мистецтво, архітектура, багато уваги приділяв опису церков), про міста або містечка (оцінював їх інфраструктуру, стан розвитку, зовнішній вигляд), про владу і ставлення до неї.

Приїхавши до Лемберга (Львів) в Австрійській державі, Галаган приділив увагу опису декількох костьолів, якості богослужіння, зазначав присутність у соборі значної кількості людей, серед яких було як вище суспільство, так і простий народ. Його дивувало, що на вулицях усі курять люльки й сигари, що вважав виявом «великої свободи в усьому». В Російській імперії існувала заборона куріння на міських вулицях, тому вуличні курці здавалися російським мандрівникам ознакою певної свободи. Відвідавши поштамт, Григорій побачив таких же грубих чиновників, як у Росії. Він відвідав цирк, біля якого «на лавках сиділи німці й перекушували»: «Скрізь помічали ми скромність, благопристойність». Визначаючи дух городян, Галаган зазначав: «Не можна сказати, щоб вони були схожі на смиренних, між тим дуже смирні, здається, покірні, не вдаються в політику, не стежать за нею; ...портрети імператора дуже рідкісні ...помітно сильний вплив монархічної влади. Цензура дуже сувора, заборонених книг дуже багато». Місто «доволі приємне, жваве» [11, с. 190-192].

Дорогою до Ольмица (Оломоуц), їдучі Моравією, Галаган бачив більш різноманітні види, «країна - заселена, готелі - краще». Юнак зазначав набожність людей у Сілезії, яка, на його думку, «перевершує все те, що він бачив у Галіції»: доволі часто зустрічалися «хрести з розп'яттями, образи, статуї, серед поля стоять каплиці, серед гаїв на деревах повішені образи, хрести». Галаган помічав зміни в одязі - «костюм ... робиться зовсім німецьким», хоча все ще лунала слов' янська мова. У місті Фрідек він бачив вулиці, наповнені людьми, які молилися й співали. Сподобались йому й дуже чисті села [11, с. 193]. Подібне зазначав і в Угорщині: гарні села, всипані садами, «славно оброблені» поля. Місцевих описував як суто німецьке суспільство, яке гарно веселиться. Розмірковуючи з приводу життя людей, Галаган припускав, що «Угорщина повинна бути щасливою країною: податний оклад дуже малий, а кошти великі, до того ж молодці-угорці встигли відстояти свої права». Йшлося про значну частину дворянства, яка перебувала в опозиції щодо централізаторської політики Габсбурзької монархії. Приїхавши в Ольмиц, він застав святкування городянами «дня звільнення свого від прусаків при Фрідріху ІІ». Далі Галаган пересувався через Богемію, зазначаючи, що «чим далі їхали, тим краще ставала країна» [11, с. 194-195].

У Богемії він відвідав Францисбад, який оцінив як «дуже чистеньке», 3 «усіх сторін - відкрите поле, вдалині видніються гори; тут вільно можна дихати, особливо малоросіянину. Рівнина надзвичайно населена, ... народ тут живе дуже добре і в достатку». Тут Григорій застав свято: народ у святкових сукнях натовпами з хоругвами і хрестами, «все йшло зі співом та музикою». Він додав, що «не помічав ніякого релігійного почуття в народі; всі, здавалося, виконували церемонію за звичаєм». Серед офіцерів національної гвардії він зустрів господаря готелю, після чого зауважив, що «хоча в Австрії національна гвардія тільки у формі, але все-таки вона є народний глас, рука народу, при першому випадку» [11, с. 196-198]. 
Баварський Вюрцбург видався Галагану більше похмурим і сумним, ніж величним, а також не дуже жвавим. Дорогою його супроводжували «надуті німці», які мало говорили. Він дивувався, що Баварія має конституцію, але народ іiї зовсім не відчуває, король керує всім, а решта тільки дивиться і мовчить. Нюрнберг він сприйняв як місто, де «взагалі не дуже люблять короля», багато грошей іде на будівництво, дорогу до Мюнхена як не дуже добре облаштовану, коли при всякій зупинці відчувається жахливий поштовх, а під час руху - знову смикання. Країна ж загалом виглядала плоскою і дуже населеною [11, с. 203-210].

У Мюнхені Галаган також застав велике народне свято «Октоберфест», мета якого заохочення промисловості: «3 усіх кінців Баварії привозять до жовтня екземпляри кращої худоби, ....привозять фрукти, овочі, інструменти для землеробства. Особлива комісія розглядає все це і роздає приз». Потім на великій галявині відбувається свято, а король привселюдно роздає нагороди. Багато уваги він приділив опису свята та вбранню місцевих, підкреслюючи: «Тірольці, багато які, особливо ті, що без бакенбард, а тільки 3 вусами, дуже мають у фізіономії багато схожості з українцями» [11, с. 211-213]. Описом мистецтва Мюнхена й закінчується щоденник. Про подальшу подорож можна дізнатися з епістолярного матеріалу.

3 Мюнхена Галаган вирушив до Ніцци, де провів осінь і зиму 1841 р., а після того разом з Ф. В. Чижовим виїхав до Неаполя, де відвідав острів Іскія з різноманітними руїнами. Відомості щодо подальшої подорожі можна отримати лише починаючи з літа 1842 р. Після Італії Галаган знову повернувся до Німеччини, помітивши такі між ними відмінності: «В Італії в усьому надзвичайна нечистота, в церквах же пилинки ніде немає, а у Німеччині навпаки - двори чистіше італійських палаців, а церкви всередині покриті павутиною, і все в пилу. Я думаю, втім, що це не походить від зневаги німців до церкви, а від бідності церков» [1, с. 42-48].

Юнаку для оздоровлення були необхідні ванни. Оскільки найкращі знаходились у Брайтоні, в Англії, але були дорогими, Галаган обрав Остенд, бо не бажав «збільшувати багатство бульдогів», тобто англійців. Проїжджаючи по річці Майн повз німецькі міста, Галаган спостерігав «великий порядок». У Дюссельдорфі він відвідав академію мистецтв. Під розповіддю юнака міститься приписка його наставника Ф. В. Чижова: «Тут все добре, тільки народ рейнський гірше сатани: грубі, зухвалі, мерзенні й, до всього цього, безчесні. Він (Г. Галаган) мав нагоду в цьому переконатися. ... Дріб'язковість, скупість, якась закосніла грубість, - все в цих проклятих німчурах». Галаган також висловив свої враження від німецьких міст: «Скільки є народів, які вдвічі більше заслуговують на покарання. ....Наприклад, тутешній народ: в Дюссельдорфі, Кельні та околицях; який грубий, безсовісний, аморальний, а між тим, як все добре у них йде!». Про Кельн він писав як про «величезне місто, дуже діяльне. Рейн дуже широкий, але околиці дуже плоскі й одноманітні» [1, с. 48-54].

Подорожуючи Бельгією, Г. П. Галаган описав Ахен як «славне місто з добре відбудованими вулицями й з прекрасними магазинами. ...Від Ахена до Люттіха (Льєж) місця по дорозі прекрасні, дуже населені і дивно, як оброблені». У Бельгії він спостерігав «дивовижне розмаїття зелені. ...Рішуче вся країна покрита садом». Люттіх 3 його жвавим, веселим, співучим народом видався йому майже Францією. Тут він «сів на паровоз і помчав зі швидкістю, про яку в Німеччині не мають поняття»: «Ми все проїжджали через великі міста, квітучі торгівлею, всюди мене дивувала незвичайна діяльність. По дорозі серед садів дуже часто трапляються фабрики, де парові машини 3 шумом говорять про діяльність. Французи всюди на паровозах роблять компліменти, сміються, жартують, проста людина тут як в якомусь вихорі». Остенд йому здався геть нудним, регулярним містом, «яке стоїть у болоті ... у нескінченній рівнині круглі вітряки та високі труби фабрик і заводів». Його загальні враження від Бельгії пов’язані зі згадками про таку саму похмуру погоду в Петербурзі. Однак при цьому він згадав і батьківщину: «Ось вам країна діяльності! Вірно, наш український плуг не зробить у повітрі тієї зміни, яку виробляють труби фабрик і заводів» [1, с. 54-58]. 
Ця країна викликала у Галагана суперечливі почуття. 3 одного боку, квітучі «абсолютно фламандські» міста комерційної Бельгії. Брюссель, Брюж (Брюгге), Гент, Антверпен, Остенд варті того, щоби проїхатись ними, побачити пофарбовані білим прекрасні будівлі, старовинні готичні споруди, великі церкви, широкі й чисті, хоча досить мляві, вулиці. 3 іншого боку, тут «до небес підноситься безліч високих труб, 3 яких густі клуби диму виходять і затьмарюють всю атмосферу». До того ж тут ви бачите міцних червонощоких і рішуче білявих чоловіків і жінок, які, однак, мають вигляд релігійний і похмурий та говорять зовсім не гармонійною мовою [1, с. 71-77].

В Італії Галаган із задоволенням писав про Венецію, де «так приємно, тихо, добре. ...Багатство всюди вражає. ...який у всьому особливий смак». Їй він протиставив Флоренцію, яка йому не сподобалась тим, що там «мало італійського! Вулицями все їздять і ходять ці нестерпні аршини - англійці чи російські панове; італійці тутешні багато в чому офранцузилися, порівняно з іншими». Важливо зауважити різницю у сприйнятті країни Галаганами: дядечко Григорія лаяв італійців, а він з тітонькою їх захищав [1, с. $88-108]$.

Більше за все Г. П. Галагана вразив Рим, на який він не міг надивуватись, але водночас був невдоволений, що місто «сповнене форестьєрів (іноземців)». У Римі він провів зиму, бачив лютневу повінь, після чого «уряд видавав хліб всім жителям, замкненим водою в своїх будинках [...] і це робили в Колізеї». Галаган застав карнавал, дивувався відсутності п’яних, пустунів, зазначав відмінність італійців (римлян) від інших народів: італійці все закидають квітами та вживають драже, тільки щоб змусити даму повернутися до себе. Форестьєри, навпаки, відрізняються брутальністю своїх манер, особливо англійці та росіяни, які тільки й намагаються, щоб зробити комунебудь боляче. «Ці безневинні забави не для грубих жителів Півночі. Італійці ні за що цього не робили», - писав він [1, с. 110-127].

У контексті проблеми формування національної ідентичності важливі міркування Г. П. Галагана стосовно церкви: «Разом з просвітництвом, перейнявши у іноземців звичаї та одяг, ми непомітно піддали і нашу православну церкву змінам, які зовсім їй не йдуть. Ми почали будувати храми в римському стилі або в зіпсованому смаку rococo $[\ldots]$ з'явилися французькі церкви [...] і ми, захопившись модою, зовсім забули про наші святі храми. .... Пора нам перестати думати, що все іноземне добре. Воно пристойно тут, а у нас - ні!». У результаті він зробив такий висновок: «...наша релігія не повинна бути піддана ніяким змінам, начальником нашої церкви $є$ сам Ісус Христос, який ніколи не перемінюється» [1, с. 122-123].

Від’їджаючи з Риму, Галаган сумував, що місто з кожним роком все більше «зникає в серцях своїх прекрасних дітей, які заражаються мерзенною холодною освіченістю заальпійських народів. Скоро [...] залишаться одні будівлі, а римлян вже не буде, будуть європейці. [...] чудові будівлі, якими ти так відрізняєшся перед усіма іншими містами в світі, й вони ще довго будуть чорніти між біленькими німецькими будинками!» [1, с. 141-144].

Мандрівка 1850-1851 рр. мала стати для Г. П. Галагана весільною (ії відкладали через революційні події 1848-1849 рр. у Свропі) і мала на меті лікування ваннами. Разом $з$ дружиною Григорій відвідав Німеччину, Бельгію, Англію, Францію, Італію. У цій подорожі вже чітко простежується еволюція його ставлення до країн і місцин, де він уже колись побував.

Г. П. Галаган приділяв увагу роздумам щодо Галіції, сподіваючись, що галичани «не впадуть до загального виру політичних ідей Заходу й залишаться вірними своїм східним братам, незважаючи на те, що відділені від них німцями». Він розмірковував над тим, що це «наш рідний край, населений нашим народом, але [...] вже занадто давно належить німцям», які «завжди гордовиті перед слов'янами» [1, с. 295-298]. Отже, як бачимо, такі подорожі сприяли також усвідомленню єдності двох Україн, які перебували у складі різних імперій.

Далі була Прага, в якій нічого не змінилося, але питання залишалося: де ж чехи у цьому «німецькому місті? [1, с. 299-300], Дрезден з його тривалою поганою погодою, 
яка, втім, не заважала ні музиці, ні гулянню німців. На думку Галагана, за ті роки, що він не бачив Німеччини, тут багато що змінилося: «Відносно матеріального - безліч залізниць, газове освітлення навіть у маленьких містах швидко поширилося в усіх напрямках. Відносно морального я знайшов ще набагато більше зміни [...] - це ліберальність, яка зовсім не йде німцям, а тим часом занадто часто висловлюється». Для нього «німці зовсім не ті: «вони стали набагато менше цікаві» [1, с. 301-311].

У Швальбасі йому подобалися прогулянки усамітненими ярами, в Емсі увагу привертали гори. А от щодо тамтешнього суспільства, яке складалося майже з німців, Галагану «було дуже нудно сидіти між крикухами-німкенями», які вирізнялися «різкістю голосу і несмаком одягу». Його дивувало, що німці взяли звичку мішати до своєї мови французькі слова, які «забирають у німецької мови останню їі гідність - оригінальність» [1, с. 306-307], дивувало також, що звичка, яка раніше належала одним пруссакам, говорити про себе з гордовитою самовпевненістю і пихою, а про всіх інших народів - 3 презирством, тепер оволоділа всіма німцями. Навіть ззовні німецький народ змінився, майже зовсім відкинувши свої національні костюми і надягнувши тепер загальну всім західним народам синю блузу [1, с. 304]. Бельгію цей дворянин називав «мирною і квітучою країною», де він «не може не захоплюватися багатством іiї міст, та й насититься ії прекрасними селами і чудовою обробкою її полів, схожих, швидше, на сади». Англія ж, на думку Галагана, «досить багато у чому служить прикладом всій Європі», а «Лондон і Париж так повні життя теперішнього, що минуле в них стоїть на досить віддаленому плані, не те, що в Італії, де самі мешканці живуть минулим часом» $[1$, с. $310-313]$.

Важливо зазначити, що, розмірковуючи про Захід, Галаган усвідомлював, що для нього головною є ідея свободи, рівності та братерства, для якої працює західне людство, яке «все прагне до рівняння і з'єднання всіх під одним прапором». Водночас він вважав, що «захід віджив [своє], що він помер, це відчувається самими західними народами [...] прийшов час, ідеї виросли, посилилися, взяли верх». Вони самі зізнаються, що «моральне життя у них зупинилося, що вони вмирають» [1, с. 302-305].

У 1861 р. Г. П. Галаган здійснив двомісячну подорож, відвідавши Німеччину, Бельгію та Британію. 1866 р. він їздив на Захід з дружиною та сином, подорож мала не лише рекреаційно-оздоровчу, але й освітньо-пізнавальну мету. Через Австрію, Баварію та Швейцарію вони дісталися Франції, відвідали курортні міста Віші та Біарріц $[1$, c. 476$]$.

3 цієї подорожі для нас цікаві зауваження Галагана щодо поляків. Адже саме тут виявились зовсім інші інтонації, ніж ті, що звучали у його текстах перед тим. Так, у листах до М. А. Рігельмана, М. В. Юзефовича, у проєкті адміністративної реформи, який він подавав міністру внутрішніх справ С. С. Ланському, звучали яскраві антипольські зауваження та пропозиції, яким чином позбутися впливу поляків на Правобережній Україні [2]. Тепер же, в’іхавши у Царство Польське, Галаган переконався, що «на кордоні його треба нам залишати нашу антипатію до ляхів [...] тут вони вдома і мають у наших очах зовсім інші права». Такі враження підтверджувались і подорожнім спілкуванням: до Варшави він «їхав у товаристві досить приємно освічених людей поляків і англійців» [1, с. 408-411] (підкреслено нами. - Т. Л., А. Ш.).

Місто-курорт Баден-Баден для нього - «кращий у Європі куточок», де можна зустріти людей елегантних, шляхетних, модних, всіх можливих європейських націй. У Кельні Галагани відвідали Стрілецьке свято, поділившись враженнями: «Страшно важко, без смаку, підмішано якимось ідіотизмом в окремих особистостях, а все разом виходить розумно» $[1$, с. 415-418]. У бельгійському Остенді насолоджувалися морем і повітрям, «якого так мало в німецьких горах». У Генті, знаменитому «у всій Свропі своїми садівниками», насолоджувались досконалими рослинами [1, с. 417-427]. Лондон, «сповнений народу, екіпажів», дивував станом своїх парків, в яких «вся трава жовта, згоріла, місцями зовсім зник і слід трави, дерева молоді вже без листу, а старі з листом дрібним і місцями зсілим» [1, с. 430-431]. У Франції він спостерігав прекрасне лісове господарство і водночас понівечення дерев через брак палива [1, с. 445]. 
Про подорож 1866 р. відомостей від самого Г. П. Галагана доволі небагато. Однак важливо зазначити його особливе ставлення до релігії. Так, у Кракові він детально описав католицьке богослужіння, багато у чому додаючи суб' єктивне ставлення до «чужої» для нього віри. Взагалі для Галагана православ'я було невід'ємною ознакою слов'янської та руської, у значенні східноєвропейської, ідентичностей. Від цього походили його інвективи проти католицтва, які інколи перетворювалися на відверту ксенофобію. Отже, католицтво використовувалося Галаганом для слов'янофільського іншування «Заходу», - як конфесія, що була, буцімто, чужою слов'янству [1, с. 444].

Висновки. Отже, уявлення Г. П. Галагана про Захід різнились залежно від певної країни або окремо взятого народу. Так, протягом кожної подорожі простежується еволюція його поглядів, зміна ставлення у більш критичну сторону. Наприклад, 3 часом він все більше недолюблював німців, хоча спочатку мав до них лише упереджене ставлення, оцінюючи риси цього народу як грубі та вкрай погані. Змінювалось $і$ ставлення до англійців чи поляків з упередженого на більш прихильне. Імпонували йому й італійці, а також французи, про виховання яких Галаган загалом відгукувався позитивно. Подібне можна сказати й щодо характеристики країн: у Німеччині він визнавав наявність прогресу, доглянутого стану, непоганий рівень життя людей, мальовничий вид. Але на фоні інших країн німецькі міста й околиці сприймалися не так приязно. Більше за все Галаган захоплювався Бельгією, особливо станом ії розвитку й доглянутості, зовнішнім виглядом країни, а також Італією, особливо Римом, з його культурними надбаннями та уподобаним Галаганом кліматом.

Ставлення Григорія Павловича до Заходу, його традицій та тенденцій розвитку можна визначити, скоріше, як скептичне. Він виступав проти некритичної практики наслідування західноєвропейських цінностей на догоду ліберальним ідеям, що шкодить власній самобутності окремої людини та народу. Ще будучи молодим, Галаган переважно звертав увагу на релігійне питання, протестуючи проти будь-яких змін або запозичень у конфесійному просторі, відстоюючи свої позиції стосовно православ'я. Згодом він звернув увагу й на національну ідентичність. Чітко простежується прискіпливе ставлення до космополітичних ідей Заходу або до «чужих» конфесій, передовсім католицької. Галаган виступав як прихильник національної самобутності народів і водночас як ревнитель православ'я. Для нього важливим виявилось збереження власної ідентичності, а не сліпе слідування західним тенденціям. Виступаючи проти космополітизму, він критикував німців за втрату оригінальності їх мови та одягу на догоду уподібненням Заходу. На думку вже дорослого Г. П. Галагана, Захід поступово вмирає, а моральне життя там зупинилося. Однак саме під впливом Заходу водночас зміцнювалась власна ідентичність Галагана як патріота своєї малої Батьківщини.

\section{REFERENCES}

1. «My vyikhaly z Sokyryntsiv...»: travelohy rodyny Halahaniv [«We left Sokyryntsi...»: travelogues of the Galagan family] (2019) / uporiad. M. Budzar, Ye. Kovalov. Kyiv: StreamArLine, 516 s. (in Russian).

2. Lytvynova, T. F. (2018). Polyaki skvoz' prizmu identichnosti ukrainskoj elity serediny XIX v. [Poles through the prism of the identity of the Ukrainian elite of the mid-19th century] In . Dobre s zle sasiedztwa. Obce - nasze - inne [Bad neighborhoods are good. Alien - our - other]. Bydgoszcz, p. 102-111 (in Russian).

3. Baranenko, S. M. (2017). Rehionalnyi vymir istoriohrafii dvorianstva v suchasnii ukrainskii istorychnii nautsi pochatku XXI st. [The regional dimension of the historiography of the nobility in modern Ukrainian historical science of the early XXI century]. Intelihentsiia i vlada. Seriia: Istoriia, vyp. 37, p. 155-166 (in Ukrainian).

4. Berelovich, V. (2018). Evropejskie obrazovatel'nye puteshestviya russkih aristokratov [European educational travels of Russian aristocrats]. In Ideal vospitaniya dvoryanstva v Evrope: XVII-XIX veka [The ideal of educating the nobility in Europe: XVII - XIX centuries]. Moskva, p. 410-444 (in Russian).

5. Betlii, O. (2012). Istoryk na pozovakh iz prostorom, abo chy mozhlyva synkhronizovana istoriia? (Rozdumy nad statteiu Antona Kotenko. Povernennia prostoru) [Historian on lawsuits with space, 
or is a synchronized story possible? (Reflections on Anton Kotenko's article. Return of space. Ukrainskyi humanitarnyi ohliad, vyp. 16-17, p. 132-151 (in Ukrainian).

6. Budzar, M. (2018). Dvorianska spilnota Livoberezhnoi Ukrainy v ego-dokumentakh z arkhivu Galaganiv [The aristocratic community of the Left Bank of Ukraine in ego-documents from the Galagan archive]. In Istorychni dzherela v ukrainskomu informatsiinomu y osvitnomu prostori: veryfikatsiia ta interpretatsiia. O. O. Salaty (Ed.). Vinnytsia, TOV «TVORY», 348 p. (in Ukrainian).

7. Budzar, M. (2016). Kulturni priorytety «novoi elity» v ukrainskomu sotsiumi XVIII st.: rodyna Halahaniv [Cultural priorities of the «new elite» in the Ukrainian society of the XVIII century: the Galagan family]. Zeszyty naukowe Uniwersytetu Jagiellonskiego. Prace historyczne. Krakow, № 143(2), p. 353-359 (in Ukrainian).

8. But, Yu. E. (2020). Kak vospityvali i chemu uchili dvoryan v Rossii i Evrope: rezul'taty mezhdunarodnogo sotrudnichestva [How the nobles were raised and taught in Russia and Europe: the results of international cooperation]. Quaestio Rossica, t. 8. № 3, p. 1039-1050 (in Russian).

9. Vul'f, L. (2003). Izobretaya vostochnuyu Evropu: Karta civilizacii v soznanii epohi Prosveshcheniya [Inventing Eastern Europe: A Map of Civilization in the Mind of the Enlightenment]. (I. Fedyukina. Trans). Moskva: NLO, 560 p. (in Russian).

10. Goperhoeva, D. R. (2018). Russkaya literatura puteshestvij pervoj poloviny XIX v.: evolyuciya temy «Rossiya - Zapad» [Russian travel literature of the first half of the 19th century: the evolution of the theme «Russia - the West»]. Vestnik BGU. Yazyk. Literatura. Kul'tura, № 2, p. 97-104 (in Russian).

11. Hryhorii Galagan. Zhurnal (1836-1841) [Gregory Galagan. Journal (1836-1841)] (2020) / uporiad. M. Budzar, Ye. Kovalov. Kyiv: StreamArLine, 248 p. (in Russian).

12. Hryshchenko, K. S. (2013). Zakordonni mandrivky yak skladova dvorianskoi kultury pershoi polovyny XIX st. (na materialakh rodyny Hiersievanovykh) [Foreign travels as a component of aristocratic culture of the first half of the XIX century. (based on the materials of the Gersevanov family)]. Naddniprianska Ukraina: istorychni protsesy, podii, postati, p. 37-43 (in Ukrainian).

13. Kovalov, Ye. A. (2019). Podorozh yak zasib piznannia svitu i samoho sebe [Travel as a means of knowing the world and oneself]. In «My vyikhaly z Sokyryntsiv ...»: trevelohy rodyny Galaganiv [«We left Sokyryntsi...»: travelogues of the Galagan family] / uporiad. M. Budzar, Ye. Kovalov. Kyiv: StreamArLine, p. 5-13 (in Ukrainian).

14. Kovalov, Ye. A. (2020). Yunatskyi shchodennyk («Zhurnal») Hryhoriia Galagana: istoriia tekstu [Youth Diary («Journal») by Hryhoriy Galahan: history of the text] In Hryhorii Galagan. Zhurnal (1836-1841) [Gregory Galagan. Journal (1836-1841)] / uporiad. M. Budzar, Ye. Kovalov. Kyiv: StreamArLine, p. $7-17$ (in Ukrainian).

15. Kotenko, A. (2010). Povernennia prostoru [Return of space]. Ukrainskyi humanitarnyi ohliad, vyp. 15, p. 45-60 (in Ukrainian).

16. Lytvynova, T. F. (2011). «Pomishchytska pravda». Dvorianstvo Livoberezhnoi Ukrainy ta selianske pytannia naprykintsi XVIII - v pershii polovyni XIX stolittia (ideolohichnyi aspekt) [«Landlord's Truth». The nobility of the Left Bank of Ukraine and the peasant question in the late eighteenth - in the first half of the nineteenth century (ideological aspect)]. Dnipropetrovs'k: Lira, 732 p. (in Ukrainian).

17. Pryluky. Fortetsia. Kulturolohichnyi chasopys [Priluki. Fortress. Cultural Journal] (2019). № 10. Cherven'. URL: http://elibrary.kubg.edu.ua/id/eprint/28857/ (in Ukrainian)

18. Smolnitska, M. (2003). Hryhorii Halahan: portret osobystosti na tli doby [Gregory Galagan: a portrait of a person against the background of the day]. Ukrainskyi istorychnyi zbirnyk, № 5, p. 169-198 (in Ukrainian).

19. Tkachenko, T. V. (2003). Hromadska ta blahodiina diialnist H. P. Halahana [Public and charitable activities G. P. Galagan]: extended abstract of Candidate's thesis. dys. ...kand. ist. nauk. Kyiv.

20. Tolochko, A. (2012). Kievskaya Rus' i Malorossiya v XIX veke [Kievan Rus and Little Russia in the XIX century]. Kyiv: Laurus, 256 p. (in Ukrainian).

21. Shirle, I. (2012). Peremena mest. Dvoryanstvo v raz'ezdah i v gostyah [Change of places. The nobility on the road and on the road]. In Dvoryanstvo, vlast'i obshchestvo v provincial'noj Rossii XVIII veka. Moskva: NLO, p. 598-623 (in Russian). 
22. Yakymenko, L. I. (2019). Dvorianstvo Naddniprianshchyny v doslidzhenniakh suchasnykh istorykiv [Nobility of the Dnieper region in the research of modern historians]. Naukovyi visnyk Uzhhorodskoho natsionalnoho universytetu. Seriia: Mizhnarodni vidnosyny, № 5, p. $43-49$ (in Ukrainian).

Received 14.02.21

Accepted 05.03.21

DOI: $10.15421 / 272107$

УДК 94(=162.1):323.281(477.54-25) «193»

\title{
О. О. Ніколаєнко
}

Харківський національний педагогічний університет імені Г. С. Сковороди

\section{ПОЛЬСЬКА СПІЛЬНОТА ХАРКОВА В ЛЕЩАТАХ СТАЛІНСЬКОГО РЕЖИМУ (30-ТІ РР. ХХ СТ.)}

\author{
E-mail: nikolajenkoolga@gmail.com \\ ORCID: 0000-0002-2294-4198
}

\begin{abstract}
Анотація. Проаналізовано державну політику у ставленні до польського населення 1930-х рр. Метою є вивчення національної політики сталінського режиму, методи іiі впровадження в одному з найбільших міст України. Основними джерелами стали документи архівів, що містять інформацію про діяльність польських громадських організацій у 1930-х рр., а також справа про ліквідацію «Польської військової організації» у 1937 р., що включає біографії засуджених поляків, матеріали слідства, допитів, винесення вироків і подальшої реабілітації невинно засуджених. Для опрацювання цих джерел використано методи аналізу й синтезу, а також спеціально-історичні методи історико-хронологічний, історико-типологічний. На початку 1930-х рр. в Харкові діяло декілька польських громадсько-культурних організацій, метою яких була інтеграція полонії міста задля підтримки національної культури - Польський клуб, школа, театр. 3 початку 1930-х рр. почалось цькування активістів цих організацій, що закінчувались публічною критикою і громадським засудженням, виключенням з партії, позбавленням місця роботи. Приводом виступало неналежне виконання завдань партії. У 1937 р. переслідування перетворились у широкомасштабні репресії, метою яких була розправа 3 польським населенням. В результаті справи «Польської військової організації» в Харкові були засуджені і розстріляні діячі харківської полонії - члени польського клубу, вчителі польської школи, рядові робітники-поляки. Їх провина полягала лише у приналежності до польської національності, а «контрреволюційна діяльність», що їм приписувалась, лише приводом до застосування смертної кари. Виконавці даної операції були слухняними гвинтиками режиму, рядовими співробітниками органів НКВС. Таким чином тоталітарна держава розправлялась із ненадійними громадянами, намагаючись перетворити суспільство у слухняну мовчазну масу. Матеріали слідчої справи свідчать і про витримку й героїзм засуджених, і про підтримку їх оточуючими. У 1957 р. справа була переглянута, а засуджені реабілітовані у зв'язку «із відсутністю у їх діях складу злочину». Лише сьогодні, з відкриттям архівів, можна встановити подробиці цієї розправи і відновити історичну справедливість. Новизна статті полягає у виявленні особливостей проведення репресивної політики режиму у ставленні до окремих національних груп.
\end{abstract}

Ключові слова: польська спільнота, Харків, репресії, справа «Польської військової організації». 